\title{
Spatial and Temporal Changes of the Green Cover of Colombo City in Sri Lanka from 1956 to 2010
}

\author{
L. S. Wickramasinghe ${ }^{1}$, S. M. C. U. P. Subasinghe ${ }^{1, \#}$ and \\ S. M. W. Ranwala ${ }^{2}$ \\ ${ }^{1}$ Department of Forestry and Environmental Science, \\ University of Sri Jayewardenepura, \\ Nugegoda, Sri Lanka \\ ${ }^{2}$ Department of Plant Sciences, \\ University of Colombo, Colombo 03, Sri Lanka \\ \#Corresponding Author: \\ Tel: (+94) 71445 0339; Fax: (+94)112 803 828; Email: upul.forestry@ gmail.com
}

\begin{abstract}
Colombo city, the commercial capital of Sri Lanka and also a popular tourist destination is currently under a redesigning program coupled with landscaping activities. Therefore it is important to investigate the spatial distribution of the green cover and its change over the time so that the findings can effectively be used to identify priority areas for restoring and revitalizing the greenery of the city. This study was conducted on mapping the green cover in all 47 wards of Colombo city for the years 1956, 1982, 2001 and 2010 by analyzing aerial photographs and IKONOS maps using Geographic Information Systems. Investigations were further extended to identify the vegetation cover\% and its change in each ward during the 54 year study period. According to the results, the green cover of Colombo city declined from $35.67 \%$ to $22.23 \%$ from 1956 to 2010. In 2010, the highest green cover (49.65\%) was reported in Narahenpita and only three other wards (Kirillipone, Cinnamon Gardens, and Thimbirigasyaya) had green cover over 30\% of the total land extent. In contrast, the green cover was less than 10\% for ten wards, i.e., Kochchikade North, Kochchikade South, Grandpas North, Masangasweediya, Panchikawatte, Fort, Gintupitiya, New Bazaar, Maligawatte, and Aluthkade East. Under the current redesigning plans, those ten wards should be given the priority to increase the green cover to re-establish a healthy environment. Expansion of built-up areas and road network can be surmised as major reasons for the gradual reduction of green cover in Colombo city.
\end{abstract}

KEYWORDS: Colombo, GIS, Green cover, Landscaping, Urban greenery

\section{Introduction}

The concept of sustainable city has become important worldwide in urban planning to rein in negative impacts which have arisen as a consequence of urbanization. 
With that concept, the planners and policy makers realized the importance of the role played by urban green areas in creating a healthy environment for the city dwellers (Kuchelmeister and Braatz, 1993). Many policy instruments and scientific evidences also emphasize the importance of retention of green spaces within cities and peripheries to ameliorate urban heat, noise emission, and pollution as well as to add aesthetic and recreational values for the wellbeing of dwellers (Bolund and Hunhammer, 1999).

Urban green areas include any type of vegetation collectively referred to green infrastructure, encompassing the entire working landscape in cities that improves air quality, reduce flash flood and assist in pollution control (Girling and Kellett, 2005). Common types of urban green spaces include street trees, courtyards, open parks, cemeteries, golf courses, vacant lots, industrial areas, and rail right of ways and forested woodlots (parks, estates and arboreta).

The open green space that should be maintained within a city is still controversial. In the $20^{\text {th }}$ century, experts in Japan, Germany and some other countries suggested that at least $40 \mathrm{~m}^{2}$ area of green space per capita should be maintained within an urban city to meet the ecological balance (Singh et al., 2010). However, $9 \mathrm{~m}^{2}$ of green space per city dweller has been adopted by the United Nations Food and Agriculture Organization (Singh et al., 2010).

Urban greening benefits the environment in number of ways and provides better quality of life for the inhabitants. Cleaning the air (Keller, 1979; Hamburg et al., 1997), reduction of air temperature (Honjo and Takekura, 1991), noise reduction (Fang and Ling, 2003), water conservation (Kuchelmeister, 1998), soil conservation (Brown, 1991), waste water management (McPherson, 2004), increase of aesthetics and human comfort (McPherson and Muchnick, 2005) are some of them.

Colombo city is the commercial capital and the largest city in Sri Lanka. With the extent of $40.78 \mathrm{~km}^{2}$, it occupies $5.6 \%$ of the total extent of Colombo district. The city attracts about 1.5 million floating population on any working day and with the addition of the resident population in the city, the total population increases to more than 2.0 million during the day time (www.buildsrilanka.com). It is estimated that, about $50 \%$ of the commuting population arrives the city for employment, to engage in commercial activities and to attend educational institutes. The rest comes to the city for various other reasons (www. buildsrilanka.com).

Colombo, being the main commercial city of Sri Lanka, is the hub for businesses as well as private business establishments. The number of vehicles entering the city has increased rapidly over the past recent years. More than 200,000 vehicles enter the Colombo city every day causing heaving traffic jams and pollution. This may include 11,000 buses, 175,000 private vehicles, 15,000 heavy vehicles (Anon, 2009). 
Sri Lanka has recently entered into a period of rapid development and as a result, many activities to improve infrastructure and residencies have been taken place in and around the Colombo city. Due to those activities, many open areas are either being modified or transformed to built-up areas. In contrast, revitalizing of the green spaces is also underway. However, with those development activities, a wellstructured urban green space management plan has to be maintained in order to retain the minimum green cover requirement of the city. Therefore mapping and quantification of the existing green cover is mandatory for developing such management plans. In addition, understanding of the changing pattern of greenery over the past few decades provides a clear insight for city planners to take necessary actions to enhance and maintain the adequate green space.

It is impossible to completely rely on the ground measurements for this type of studies and therefore use and analysis of land cover data obtained from remote sensing and geographic information system (GIS) techniques become highly valuable and common (Singh, 1998; Decker, 2001; Lu et al., 2004; King and Locke, 2013). The growing availability of geo-referenced imagery has also led such interpretation for vegetation mapping for the past to the future. Therefore, the present study was conducted based on map analysis in GIS to examine the green cover change of Colombo city from 1954 to 2010.

\section{Methodology}

\section{Study Area and Duration}

Due to the recent rapid development and the importance as the commercial capital, the entire Colombo city was selected for the present study. Colombo city (Colombo Municipal Council) is located in the Colombo District of the Western Province of Sri Lanka. It consists of 47 Municipal wards which had initially been demarcated for the administration purpose. The total extent of the Colombo city is $40.78 \mathrm{~km}^{2}$ and Cinnamon Garden is the largest ward $\left(3.68 \mathrm{~km}^{2}\right)$ while Aluthkade West is the smallest $\left(0.15 \mathrm{~km}^{2}\right)$.

It was decided to investigate the green cover change for the last 54 years, i.e., from 1956 to 2010 as the development was quite rapid in Colombo city during that period. Depending on the availability of the maps and for the purpose of comparison, the entire 54 year duration was divided into three periods as Period I (1956-1982), Period II (1982-2001) and Period III (2001-2010) for the analysis.

\section{Maps Used}

Satellite imageries were not available for the years 1956 and 1982 and therefore aerial photographs of 1: 20,000 scale were used for the early periods. High resolution IKONOS images (4 $\mathrm{m}$ spatial resolution) were available for 2001 and 2010. In addition, GIS layers of different wards of the Colombo city were obtained for the year 2010 from the Urban Development Authority. A digital land use map of 
Colombo city for 1982 was also obtained from the Urban Development Authority to identify the ward boundaries required for the base map preparation.

\section{Georeferenncing, Base Map Preparation and Map Analysis}

Two IKONOS images (2001 and 2010) were already georeferenced and therefore additional changes were not required. Two aerial photographs of 1956 and 1982 were georeferenced using GIS road layer of 2010 and IKONOS image of 2001.

In accordance with the four years, i.e., 1956, 1982, 2001 and 2010 used as the delimits of the periods I, II and III, four GIS base maps were prepared using aerial photographs and IKONOS images. The green spaces in Colombo city for the above four years were separately digitized by "On Screen Digitizing" method using Arc GIS 9.3 software. Digitized green cover included tree crowns of individuals and groups of trees, lawns, marshes and paddy fields which are all inclusive in an urban forest defined by Girling and Kellett (2005). As a result, four digital map layers were prepared for the Colombo city for years 1956, 1982, 2001 and 2010 to depict the green cover.

Wards boundary layer was then overlaid with the green cover layer for each year to complete the four base maps. The green cover in each ward was extracted using the clip tool. The extents of green cover in each ward were separately calculated for 1956, 1982, 2001 and 2010 using in the attribute tables.

The green cover in all 47 wards for four respective years was calculated in this manner. Then the percentage of green cover for each ward was separately calculated using equation 1. Equation 2 was used to calculate the total green cover\% for the entire Colombo city for each year.

$$
\begin{aligned}
& \text { Green Cover } \%=\frac{\text { Total green cover of particular ward, } \mathrm{km}^{2}}{\text { Total land extent of the above ward, } \mathrm{km}^{2}} \times 100 \\
& \text { Green Cover } \%=\frac{\text { Total green cover }, \mathrm{km}^{2}}{\text { Total land extent, } \mathrm{km}^{2}} \times 100
\end{aligned}
$$

The rate of green cover change was estimated by calculating the green cover change during each period and then dividing it by number of years consistent for that particular period. This was calculated for the whole Colombo city area as well as for each ward separately. After the calculations mentioned above, new maps were created using ArcGIS 9.3 software to depict the green cover distribution in each year. 


\section{Results}

Total Green Cover in Colombo City in Years 1956, 1982, 2001 and 2010

Table 1 and Figure 1 illustrate the change of the green space in the Colombo city from 1956 to 2010. The green cover in Colombo city was $35.67 \%\left(14.54 \mathrm{~km}^{2}\right)$ in 1956 , which was reduced to $32.40 \%\left(13.20 \mathrm{~km}^{2}\right)$ in year 1982 , and further reduced to $31.25 \%\left(12.74 \mathrm{~km}^{2}\right)$ in year 2001 (Table 1).

Table 1. Change of the green cover in Colombo city

\begin{tabular}{cccccc}
\hline Year & $\mathbf{1 9 5 6}$ & $\mathbf{1 9 8 2}$ & $\mathbf{2 0 0 1}$ & $\mathbf{2 0 1 0}$ & $\begin{array}{c}\text { Total change\% } \\
(\mathbf{1 9 5 6 - 2 0 1 0})\end{array}$ \\
\hline $\begin{array}{c}\text { Total green cover } \\
\left(\mathrm{km}^{2}\right)\end{array}$ & 14.54 & 13.20 & 12.74 & 9.06 & -5.49 \\
\hline $\begin{array}{c}\text { Green cover }(\%) \\
\text { Rate of change } \\
\left(\mathrm{km}^{2} \mathrm{yr}^{-1}\right)\end{array}$ & 35.67 & 32.40 & 31.25 & 22.23 & -13.44 \\
\hline
\end{tabular}

The total green cover in Colombo city in 2010 was $22.23 \%\left(9.06 \mathrm{~km}^{2}\right)$. Further, the annual green cover reduction in the Colombo city from 1956 to 2010 was 0.10 $\mathrm{km}^{2} \mathrm{yr}^{-1}$. However, showing a rapid decline, the green cover was reduced at a rate of $0.41 \mathrm{~km}^{2} \mathrm{yr}^{-1}$ for the Period III from 2001 to 2010 (Figure 2). 

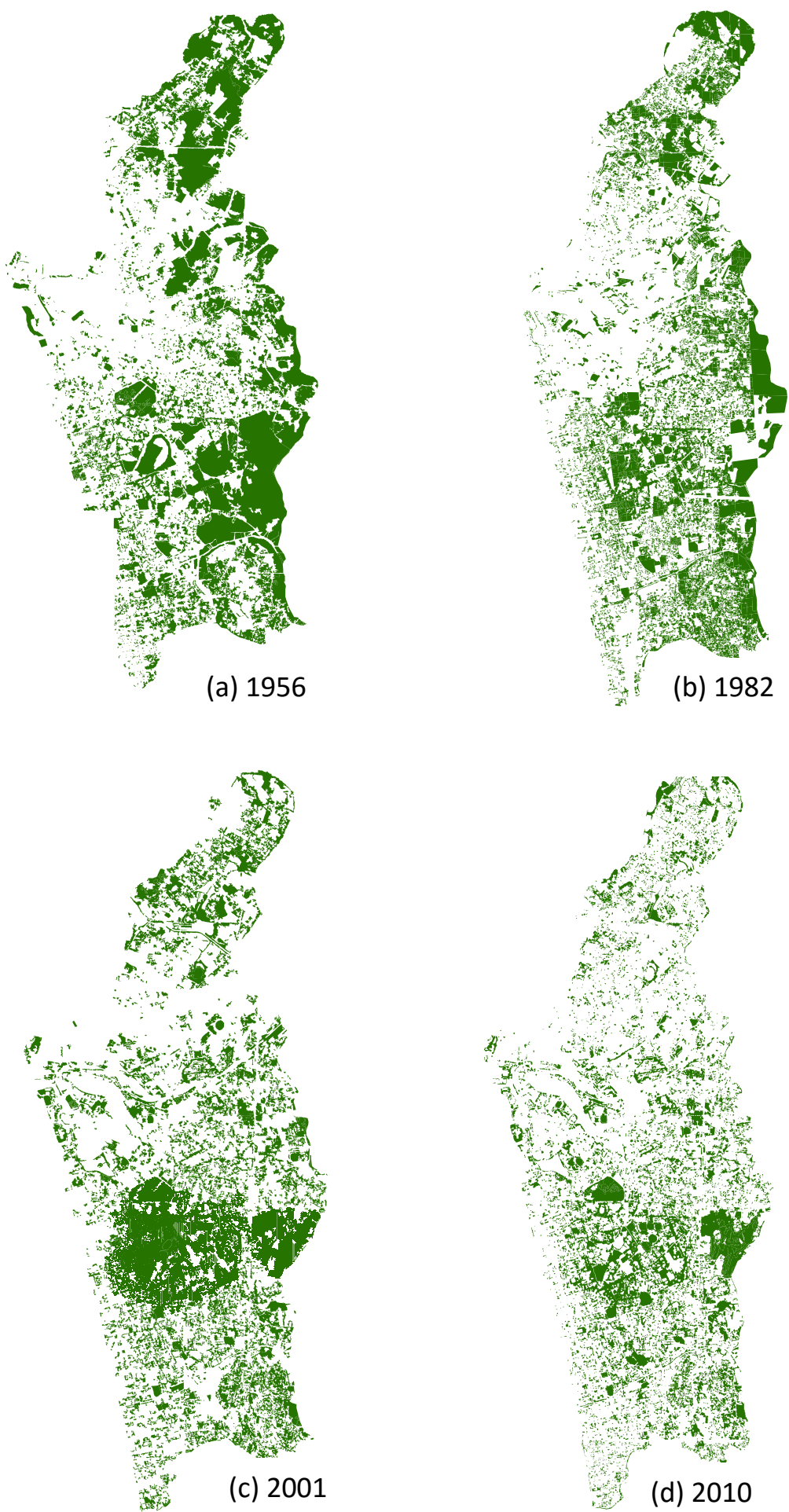

Figure 1. Change of the green cover in Colombo city from 1956 to 2010 

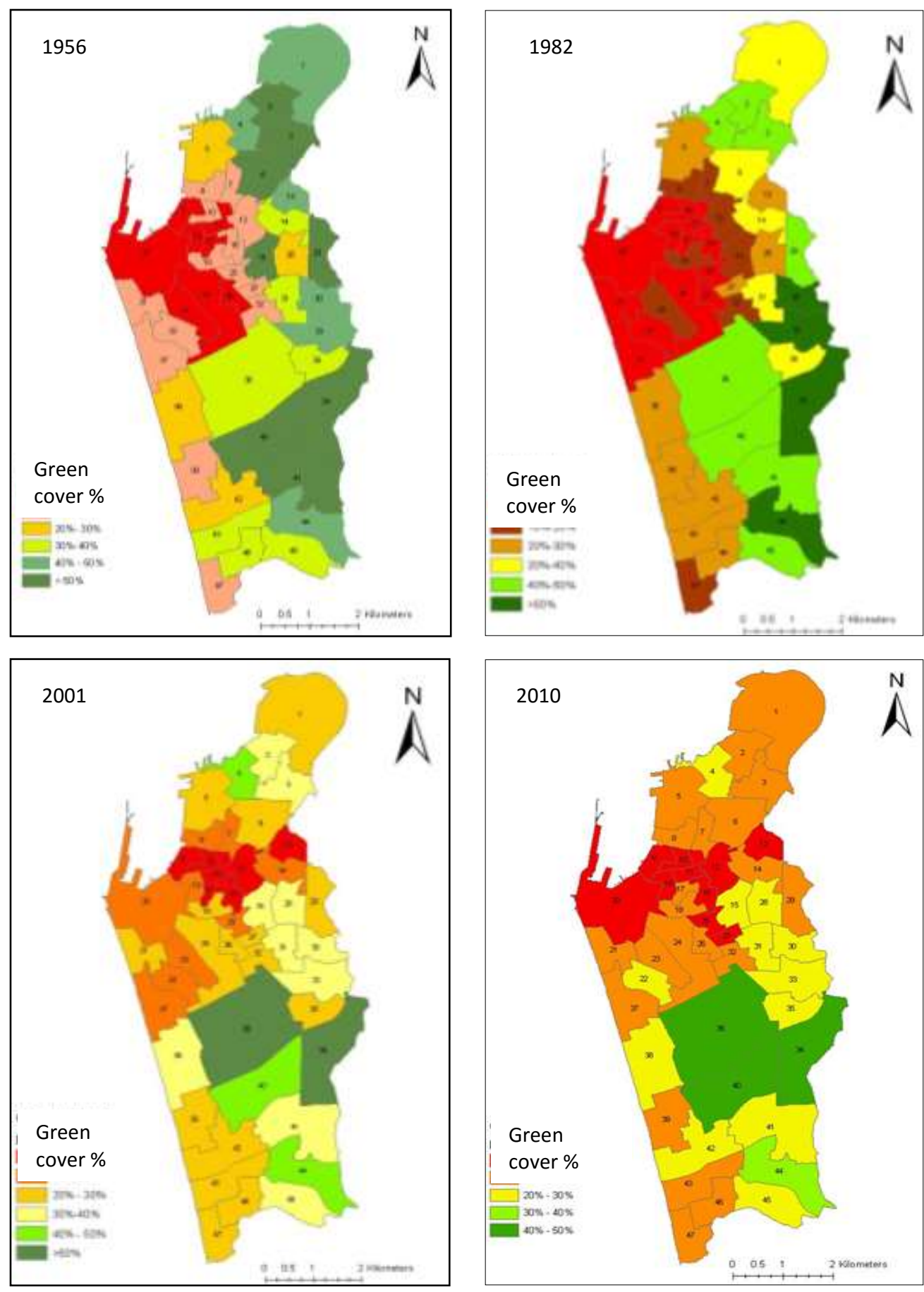

Figure 2. Percentage green cover in wards of Colombo city 
Spatial distribution of green cover in Colombo city in different wards for the study period

Table 2 illustrates the green cover extents of different years in each ward of Colombo city and Table 3 categorizes all 47 wards into different classes based on the \%green cover in 2010. Based on those information, the green space change in different years of the selected 54 year period is given below.

Table 2. Green cover in 47 wards of Colombo city from 1954 to 2010

\begin{tabular}{|c|c|c|c|c|c|c|c|c|c|}
\hline \multirow[t]{2}{*}{ No } & \multirow[t]{2}{*}{ Name } & \multirow{2}{*}{$\begin{array}{c}\text { Ext } \\
\left(\mathbf{K m}^{2}\right)\end{array}$} & \multicolumn{4}{|c|}{ Green cover \% } & \multicolumn{3}{|c|}{$\begin{array}{c}\text { Rate of change \% } \\
\left(\mathbf{y r}^{-1}\right)\end{array}$} \\
\hline & & & 1956 & 1982 & 2001 & 2010 & P I & P II & P III \\
\hline 1 & Mattakkuliya & 2.74 & 45.41 & 38.46 & 22.96 & 15.99 & -0.27 & -0.82 & -0.78 \\
\hline 2 & Modara & 0.68 & 61.83 & 44.57 & 38.32 & 17.02 & -0.66 & -0.33 & -2.37 \\
\hline 3 & Mahawatte & 0.79 & 50.33 & 41.02 & 36.50 & 17.15 & -0.36 & -0.24 & -2.15 \\
\hline 4 & Aluth Mawatha & 0.67 & 40.54 & 46.23 & 43.99 & 20.92 & 0.22 & -0.12 & -2.56 \\
\hline 5 & Lunupokuna & 1.17 & 23.82 & 21.86 & 23.49 & 11.70 & -0.08 & 0.09 & -1.31 \\
\hline 6 & Bloemendhal & 1.01 & 65.44 & 39.81 & 27.33 & 10.62 & -0.99 & -0.66 & -1.86 \\
\hline 7 & Kotahena East & 0.30 & 17.84 & 18.09 & 14.31 & 11.03 & 0.01 & -0.20 & -0.36 \\
\hline 8 & Kotahena West & 0.40 & 11.29 & 13.79 & 12.52 & 12.99 & 0.10 & -0.07 & 0.05 \\
\hline 9 & $\begin{array}{c}\text { Kochchikade } \\
\text { North }\end{array}$ & 0.33 & 1.38 & 4.27 & 2.76 & 4.89 & 0.11 & -0.08 & 0.24 \\
\hline 10 & Gintupitiya & 0.19 & 12.45 & 7.99 & 3.76 & 7.94 & -0.17 & -0.22 & 0.46 \\
\hline 11 & Masangasweediya & 0.24 & 4.17 & 6.30 & 5.76 & 7.28 & 0.08 & -0.03 & 0.17 \\
\hline 12 & New Bazaar & 0.54 & 16.03 & 12.11 & 8.02 & 8.66 & -0.15 & -0.22 & 0.07 \\
\hline 13 & Grandpas North & 0.45 & 47.67 & 23.20 & 6.67 & 7.10 & -0.94 & -0.87 & 0.05 \\
\hline 14 & Grandpas South & 0.60 & 30.78 & 31.15 & 17.58 & 12.42 & 0.01 & -0.71 & -0.57 \\
\hline 15 & Maligawatte West & 0.54 & 68.35 & 13.81 & 35.19 & 23.33 & -2.10 & 1.13 & -1.32 \\
\hline 16 & Aluthkade East & 0.27 & 14.00 & 5.43 & 7.25 & 9.58 & -0.33 & 0.10 & 0.26 \\
\hline 17 & Aluthkade West & 0.15 & 7.70 & 6.38 & 16.94 & 11.25 & -0.05 & 0.56 & -0.63 \\
\hline 18 & Kehelwatte & 0.31 & 10.48 & 19.13 & 26.00 & 16.48 & 0.33 & 0.36 & -1.06 \\
\hline 19 & $\begin{array}{c}\text { Kochchikade } \\
\text { South }\end{array}$ & 0.23 & 2.76 & 1.91 & 13.03 & 6.61 & -0.03 & 0.59 & -0.71 \\
\hline 20 & Fort & 2.13 & 5.27 & 2.70 & 10.57 & 7.76 & -0.10 & 0.41 & -0.31 \\
\hline 21 & Kompannaweediya & 0.62 & 14.55 & 4.22 & 22.29 & 13.95 & -0.40 & 0.95 & -0.93 \\
\hline 22 & Wekanda & 0.55 & 12.43 & 8.71 & 19.70 & 20.13 & -0.14 & 0.58 & 0.05 \\
\hline 23 & Hunupitiya & 0.66 & 8.17 & 10.93 & 15.01 & 16.13 & 0.11 & 0.21 & 0.12 \\
\hline 24 & Suduwella & 1.32 & 6.11 & 10.93 & 21.44 & 16.97 & 0.19 & 0.55 & -0.50 \\
\hline
\end{tabular}




\begin{tabular}{|c|c|c|c|c|c|c|c|c|c|}
\hline \multirow[t]{2}{*}{ No } & \multirow[t]{2}{*}{ Name } & \multirow{2}{*}{$\begin{array}{c}\text { Ext } \\
\left(\mathbf{K m}^{2}\right)\end{array}$} & \multicolumn{4}{|c|}{ Green cover \% } & \multicolumn{3}{|c|}{$\begin{array}{c}\text { Rate of change \% } \\
\left(\mathrm{yr}^{-1}\right)\end{array}$} \\
\hline & & & 1956 & 1982 & 2001 & 2010 & P I & P II & P III \\
\hline 25 & Panchikawatte & 0.26 & 12.48 & 6.48 & 11.44 & 7.68 & -0.23 & 0.26 & -0.42 \\
\hline 26 & Maradana & 0.27 & 7.77 & 7.70 & 21.08 & 11.75 & 0.00 & 0.70 & -1.04 \\
\hline 27 & Maligakanda & 0.18 & 12.05 & 22.15 & 27.47 & 8.92 & 0.39 & 0.28 & -2.06 \\
\hline 28 & Maligawatte East & 0.60 & 22.53 & 29.41 & 30.89 & 21.64 & 0.26 & 0.08 & -1.03 \\
\hline 29 & Dematagoda & 0.73 & 53.92 & 45.92 & 28.13 & 11.41 & -0.31 & -0.94 & -1.86 \\
\hline 30 & Wanatamulla & 0.59 & 49.25 & 61.11 & 34.56 & 25.35 & 0.46 & -1.40 & -1.02 \\
\hline 31 & Kuppiyawatta East & 0.59 & 37.08 & 39.06 & 35.06 & 28.76 & 0.08 & -0.21 & -0.70 \\
\hline 32 & $\begin{array}{c}\text { Kuppiyawatta } \\
\text { West }\end{array}$ & 0.38 & 17.05 & 16.82 & 26.65 & 15.96 & -0.01 & 0.52 & -1.19 \\
\hline 33 & Borella North & 1.02 & 42.69 & 57.32 & 32.88 & 21.81 & 0.56 & -1.29 & -1.23 \\
\hline 34 & Narahenpita & 1.89 & 81.69 & 63.48 & 53.07 & 49.65 & -0.70 & -0.55 & -0.38 \\
\hline 35 & Borella South & 0.65 & 34.49 & 34.90 & 24.99 & 20.01 & 0.02 & -0.52 & -0.55 \\
\hline 36 & Cinnamon Gardens & 3.68 & 39.27 & 46.03 & 59.93 & 41.30 & 0.26 & 0.73 & -2.07 \\
\hline 37 & Kollupitiya & 0.97 & 10.93 & 9.94 & 18.63 & 13.56 & -0.04 & 0.46 & -0.56 \\
\hline 38 & Bambalapitiya & 1.48 & 26.71 & 21.61 & 30.62 & 21.23 & -0.20 & 0.47 & -1.04 \\
\hline 39 & Milagiriya & 0.96 & 15.72 & 21.93 & 23.97 & 16.13 & 0.24 & 0.11 & -0.87 \\
\hline 40 & Thimbirigasyaya & 1.88 & 53.67 & 48.62 & 49.77 & 43.00 & -0.19 & 0.06 & -0.75 \\
\hline 41 & Kirillipone & 1.83 & 68.25 & 49.56 & 35.86 & 27.42 & -0.72 & -0.72 & -0.94 \\
\hline 42 & Havelock Town & 1.31 & 26.46 & 29.41 & 28.94 & 27.55 & 0.11 & -0.03 & -0.15 \\
\hline 43 & Wellawatte North & 0.94 & 30.91 & 20.27 & 29.47 & 14.11 & -0.41 & 0.48 & -1.71 \\
\hline 44 & Kirillipone & 1.39 & 49.52 & 59.78 & 54.07 & 32.22 & 0.39 & -0.30 & -2.43 \\
\hline 45 & Pamankada East & 0.99 & 38.90 & 49.02 & 32.32 & 20.61 & 0.39 & -0.88 & -1.30 \\
\hline 46 & Pamankada West & 0.63 & 38.53 & 26.48 & 23.38 & 13.87 & -0.46 & -0.16 & -1.06 \\
\hline 47 & Wellawatte South & 0.67 & 13.67 & 12.92 & 21.30 & 12.68 & -0.03 & 0.44 & -0.96 \\
\hline
\end{tabular}

\section{Year 1956}

The highest green cover, viz. 81.69\% in 1956 was reported in Narahenpita (Table 2). Inclusive of Narahenpita, eight wards, i.e., Maligawatte West, Kirillipone, Bloemandhal, Modara, Dematagoda, Thimbirigasyaya and Mahawatte had the green cover over $50 \%$ of the total land area (Figure 2). The lowest green cover $(1.38 \%$ ) was reported for Kochchikade North. However, even in 1956, the green cover was found less than $10 \%$ in eight wards viz., Kochchikade North and South, Masangasweediya, Sudewella, Fort, Aluthkade West, Maradana, Hunupitiya. The remaining 21 wards had green cover varying from 30 to $50 \%$ (Figure 2). 


\section{Year 1982}

The highest green cover was recorded from Wanathamulla (61.11\%) in 1982 (Table 2). Other than Wanathamulla, only Narahenpita, Borella North and Kirillipone had green cover more than 50\%. Seventeen wards showed the green cover over $30 \%$, but lower than 50\% (Table 2, Figure 2). The lowest green spacer was reported in Kochchikade South (1.91\%) and altogether, it was less than $10 \%$ for 13 wards (Table 3).

Table 3. Change in number of wards having different green cover percentage between 1956- 2010.

\begin{tabular}{ccccccc}
\hline Year & \multicolumn{7}{c}{ Green cover class } \\
\cline { 2 - 7 } & $<\mathbf{1 0 \%}$ & $\mathbf{1 0 - 2 0 \%}$ & $\mathbf{2 0 - 3 0 \%}$ & $\mathbf{3 0 - 4 0 \%}$ & $\mathbf{4 0 - 5 0 \%}$ & $>\mathbf{5 0 \%}$ \\
\hline 1956 & 8 & 14 & 4 & 7 & 6 & 8 \\
1982 & 12 & 9 & 9 & 5 & 8 & 4 \\
2001 & 6 & 10 & 16 & 10 & 2 & 3 \\
2010 & 10 & 21 & 12 & 1 & 3 & 0 \\
\hline
\end{tabular}

\section{Year 2001}

In the year 2001, only three wards, i.e., Cinnamon Gardens, Narahenpita and Kirillipone had green cover over 50\% (Figure 2). Among those wards, Cinnamon Gardens had the highest green cover, viz., 59.93\% in 2001 (Table 3). Wards which had green cover greater to $30 \%$ were reduced to 15 in 2001, and the lowest percentage of green cover $(2.76 \%)$ was reported in Kochchikade North (Table 2). However, only six wards had the green cover less than $10 \%$ in 2001 . Those wards are Kochchikade North, Gintupitiya, Masangasweediya, Grandpas North, Aluthkade East and New Bazaar (Figure 2).

\section{Year 2010}

None of the wards had green cover exceeding $50 \%$ of the total land extent in 2010 (Table 2, Figure 2). The highest green cover was recorded in Narahenpita (49.65\%). Altogether 16 wards showed the green cover higher than 20\% (Table 3). Among these wards, however, only four wards, viz., Kirillipone, Cinnamon Gardens, Thimbirigasyaya and Narahenpita had the green cover over 30\% (Table 3). The lowest green cover was reported in Kochchikade North $(4.89 \%)$ in 2010. In addition, the green cover was less than $10 \%$ in ten wards. All other 21 wards had the green cover varying from $10 \%$ to $20 \%$ (Table 2, Figure 2).

There were eight wards with green cover over $50 \%$ in 1956 which was reduced to four wards in 1982 and three in 2010. None of the wards had green cover over 50\% in 2010. In 2010, only three wards were reported with the green cover between 40$50 \%$, but six wards were in that category in 1956. A total of 14 wards had the green cover between 10-20\% in 1956 and that number has increased to 21 wards in 2010. 


\section{Discussion}

The present study revealed that $36.67 \%$ of the green cover prevailed in Colombo city in 1956 had been reduced to $22.23 \%$ in 2010 . This is a $13.44 \%$ reduction over the 54 year period. During only the period from 2001 to 2010, the green cover has been reduced by $9.02 \%$. The decline of the green cover was $0.05 \mathrm{~km}^{2} \mathrm{yr}^{-1}$ in the period I (from 1954 to 1982), $0.02 \mathrm{~km}^{2} \mathrm{yr}^{-1}$ during the period II (from 1982 to 2001) and $0.41 \mathrm{~km}^{2} \mathrm{yr}^{-1}$ during the period III (from 2001 to 2010). The rate of green cover loss during different time periods clearly shows the severity of loosing green habitats. This situation is much severe in the period III (from 2001 to 2010), because only four wards had the green space more than $30 \%$ and only in 14 wards had it between $20 \%$ to $30 \%$.

A considerable rate of loss of green space was also reported in period I (1956-1982) in Maligawatte West which was $2.1 \% \mathrm{yr}^{-1}$ compared to other wards which decreased at a rate less than $1 \% \mathrm{yr}^{-1}$. The highest rate of increasing green space $\left(0.56 \% \mathrm{yr}^{-1}\right)$ was observed in Borella North for the period III.

In period II (1982-2001), the highest rate of green cover loss, i.e., $1.4 \% \mathrm{yr}^{-1}$ was recorded from Wanathamulla. Borella North also showed a considerably high rate of green cover loss $\left(1.29 \% \mathrm{yr}^{-1}\right)$. Maligawatte West reported the highest rate of green cover increase which was $1.13 \% \mathrm{yr}^{-1}$.

During the period III (2001-2010), the number of wards showing a substantial decreasing rates of green cover loss has increased. Those wards are Aluth Mawatha, Modara, Mahawatte, Cinnamon Gardens and Maligakanda and the decline of all other wards varied from $2.06 \% \mathrm{yr}^{-1}$ to $2.56 \% \mathrm{yr}^{-1}$. Dematagoda, Bloemendhal, Wellawatte North, Maligawatte West, Lunupokuna, Pamankada East, Borella North, Kuppiyawatta West, Kehelwatte, Pamankada West, Bambalapitiya, Maradana and Maligawatte East also had high loss of the green cover at the rate between $1.00 \% \mathrm{yr}^{-1}$ to $1.86 \% \mathrm{yr}^{-1}$. This clearly demonstrated that, in many wards, the decreasing rate of green cover was comparatively higher in the period 20012010 than that of other two previous periods. Only a few wards, viz. Ginthupitiya, Kochchikade North, Aluthkade East, Masangaswadiya, Hunupitiya, New Bazaar, Kotahena West, Grandpass North and Wekanda showed increasing rate of green cover during the period III. However, those increment rates were very low in compared with the decrease of the most of the wards.

According to the comparison made among three different periods, Hunupituya was the only ward in Colombo city in which the green cover kept increasing for all three periods even at a low rate. Ten wards reported the decrease of green cover for all three periods. Those wards are; Mattakkuliya, Modara, Mahawatte, Bloemandhal, Dematagoda, Narahenpita, Kirillipone and Pamankada West. Among those wards, Narahenpita, Kirillipone and Modara had the green cover of $81.69 \%, 68.25 \%$ and $61.83 \%$ respectively in 1956 . Narahenpita had lost nearly half of its green cover 
from 1956 to 2010 . The green cover loss of Kirillipone in the three periods was $18.69 \%, 13.70 \%$ and $8.44 \%$ respectively. The green cover loss in Modara was $17.25 \%$ during the period I and $21.30 \%$ during the period III while Bloemandhal lost the green cover by $25.63 \%, 12.48 \%$ and $16.71 \%$ respectively during the three periods. Mattakkuliya lost $6.95 \%, 15.50 \%$ and $6.98 \%$ of green cover during period I, II and III respectively. It was evident that conversion of much of paddy fields and marshy lands to built-up areas has caused the above reduction in Mattakkuliya. The green cover loss in Dematagoda was considerable in period II and III which were $17.79 \%$ and $16.72 \%$ respectively. The loss of green cover loss in Mahawatte and Pamankada West from 1956 to 2010 was a decrease from $50.33 \%$ to $17.15 \%$ and $38.53 \%$ to $13.87 \%$ respectively.

Within the cities, green space is not always equitably distributes (Wolch et al., 2014). Over the past two decades, the uneven accessibility of urban green space have become recognized as an environment justice issue as awareness of its importance to public health has been recognized (Dai, 2011; Jennings et al., 2012). However, due to the dearth of in-depth quantitative information of land use change in Colombo city, the exact reasons for the green space loss cannot be fully explained. However, by carefully observing the maps used for this study, it is evident that infrastructure development due to build up areas and expansion of road network are the main causes of this loss. In addition, fragmentation of lands into small lots was also evident from the map analysis. All these might have contributed to the reduction of the green cover in Colombo city over the study period.

Asia is urbanizing at a rapid rate (Lindfield and Steinberg, 2012) and by mid-2022, $55 \%$ of the Asians will live in the urban areas (United Nations, 2004). The population in the Colombo city will also increase in future and it can be expected that more development activities will be taken place within the city to cater the ever increasing population. If this scenario happens to be continued, the sustainability of the Colombo city will be threatened. Therefore, careful attention should be given to conserve and upgrade the existing green spaces in the Colombo city, especially for the wards with low extents of green cover. Such attention has been given in the developed countries over the developing countries in urban planning. For example, the major cities of Austria, France, Italy, Netherlands, Poland and Spain maintain highly effective environment plans (European Union, 2010).

We recommend that, at least the wards containing green cover less than $20 \%$ should be upgraded. Those wards are Kochchikade North and South, Ginthupitiya, Masangasweediya, New Bazaar, Grandpas North, Aluthkade East, Fort, Panchikawatte and Maligawatte. Potential available spaces for tree planting should be identified specially in wards with a low percentage of green cover in the Colombo city. Increased canopy cover where possible in the private realm should be encouraged as private lands will also contribute to the urban settings. The potential of applicability of vertical gardens and roof gardens in areas where space is limited for tree planting has to be explored as an alternative way to increase the green cover of the Colombo city. 


\section{References}

Anon. (2009). “Are you always behind the schedule?”, Ecologi, 3(6):1-2.

Bolund P. and Hunhammar, S. (1999). "Ecosystem services in urban areas", Ecological Economics, 29: 293-301.

Brown W. J. (1991). "Landslide control on North Island, New Zealand", Geographical Review, 81: 457-472.

Dai D. (2011). "Racial/ethnic and socioeconomic disparities in urban green space accountability: where to intervene?", Landscape and Urban Planning, 102(4): 234244.

Decker D. (2001). GIS Data Sources. John Wiley and Sons, New York.

European Union. (2010). Making Our Cities Attractive and Sustainable: How the European Union Contributes to Improving the Urban Environment. Luxembourg Publications of European Union, Belgium.

Fang C. F. and Ling D. L. (2003). "Investigation of the noise reduction provided by tree belts”, Landscape and Urban Planning, 63: 187-195.

Hamburg S. P., Harris N., Jaeger J., Karl T. R. McFarland M., Mitchell J. F. B., Openheimer M., Santer S., Schneider S., Trenberth K. E. and Wigley T. M. L. (1997). Common Questions About Climate Change. United Nations Environment Program, World Meteorology Organization.

Honjo T. and Takakura T. (1991). "Simulation of thermal effects of urban green areas on their surrounding areas", Energy and Buildings, 15-16: 433-446.

Girling C. and Kellett R. (2005). Skinny Streets and Green Neighborhoods: Design For Environment and Community. Island Press, Washington D.C.

Jennings V. Johnson-Gaither C., Gregg R. S. (2012). "Promoting environment justice through green space access: A synopsis", Environment Justice, 5(1): 1-7.

Keller T. (1979). The Possibilities of Using Plants to Alleviate the Effects of Motor Vehicles. Transport and Road Research Laboratory Symposium Report 513, Washington D.C.

King K. L. and Locke D. H. (2013). "A Comparison of three methods for measuring local urban tree canopy cover", Arboriculture and Urban Forestry, 39(2): 62-67.

Kuchelmeister G. (1998). Urban Forestry in the Asia-Pacific Region: Status and Prospectus. Asia- Pacific Forestry Sector Outlook Study. FAO Working Paper Series No. 44. FAO, Rome.

Kuchelmeister G. and Braatz S. (1993). "Urban forestry revisited”, Unasylva, 44: 13-18. 
Lindfield M. and Steinberg F. (2012). Green Cities. Asian Development Bank Series, Philippines.

Lu, D., Mausel P., Brondi'Zio. E., and Moran E. (2004). "Change detection techniques", International Journal of Remote Sensing, 25(12): 2365-2407.

McPherson E. G. (2004). "Benefits of trees: Watershed, energy and air", Arborist News, 13(6): 29-36.

McPherson E. G. and Muchnick J. (2005). "Effects of tree shades on asphalt concrete pavement performance", Journal of Arboriculture, 31(6): 303-309.

Singh A. (1998). "Digital change detection techniques using remotely sensed data", International Journal of Remote Sensing, 10: 989-1003.

Singh V. S., Pandey D. N. and Chaudhry P. (2010). Lessons for Jaipur, Rajasthan, India Occasional Paper No. 1/2010, Rajasthan State Pollution Control Board, India.

United Nations. (2004). World Urbanization Prospect: The 2003 Revision. New York.

Wolch J. R., Byrne J. and Newell J. P. (2014). "Urban green space, public health and environment justice: The challenge of making cities 'just green enough', Landscape and Urban Planning, 125: 234-244.

www.buildsrilanka.com [Accessed on 29th June 2013]. 